\title{
Wheat (Triticum aestivum L.) Yield and Yield Components as Influenced by Herbicide Application in Kaffa Zone, Southwestern Ethiopia
}

\author{
Getachew Mekonnen (iD \\ Wolkite University, College of Agriculture, Wolkite, Ethiopia \\ Correspondence should be addressed to Getachew Mekonnen; dessiemekdes@yahoo.com
}

Received 29 September 2021; Revised 26 November 2021; Accepted 12 January 2022; Published 4 March 2022

Academic Editor: Vera Popovic

Copyright (c) 2022 Getachew Mekonnen. This is an open access article distributed under the Creative Commons Attribution License, which permits unrestricted use, distribution, and reproduction in any medium, provided the original work is properly cited.

\begin{abstract}
In order to identify the effect of herbicidal weed control practices on yield components and yield of wheat, the study was conducted at Kocha kebele in Chena district of Kaffa zone, Southwestern Ethiopia. 2,4-D amine salt $\left(0.5 \mathrm{~kg} \mathrm{ha}^{-1}, 1 \mathrm{~kg} \mathrm{ha}^{-1}\right.$, and $1.5 \mathrm{~kg} \mathrm{ha}^{-1}$ ) supplemented with one hand weeding 30 days after chemical application, clodinafop-propargyl $6 \%+$ fluroxypyr $12 \%$ $\left(0.5 \mathrm{~kg} \mathrm{ha}^{-1}, 0.75 \mathrm{~kg} \mathrm{ha}^{-1}\right.$, and $\left.1 \mathrm{~kg} \mathrm{ha}^{-1}\right)$ supplemented with one hand weeding 30 days after chemical application, pyroxsulam $\left(0.4 \mathrm{~kg} \mathrm{ha}^{-1}, 0.5 \mathrm{~kg} \mathrm{ha}^{-1}\right.$, and $\left.0.6 \mathrm{~kg} \mathrm{ha}^{-1}\right)$ supplemented with one hand weeding 30 days after chemical application, 2,4-D amine salt at $1 \mathrm{~kg} \mathrm{ha}^{-1}$, clodinafop-propargyl $6 \%+$ fluroxypyr $12 \%$ at $0.75 \mathrm{~kg} \mathrm{ha}^{-1}$, pyroxsulam at $0.5 \mathrm{~kg} \mathrm{ha}^{-1}$, two hand weeding 30 and 45 days after crop emergence, weed-free check, and weedy check (unweeded) were the weed control treatments. Fifteen treatments were used for the trial and arranged in a randomized complete block design with three replications. The treatments had a significant effect on weed community, dry matter of weeds, parameters on weed control, phenology and growth parameters, and yield components and yield of wheat. The minimum total weed dry biomass was recorded in plots treated with clodinafoppropargyl $6 \%$ + fluroxypyr $12 \%$ at $1 \mathrm{~kg} \mathrm{ha}^{-1}+$ one hand weeding at crop harvest. The highest weed control efficiency (93.30\%) and herbicide efficiency index (27.06\%) and the lowest weed index (14.18\%) were recorded with the application of clodinafoppropargyl $6 \%$ + fluroxypyr $12 \%$ at $1 \mathrm{~kg} \mathrm{ha}^{-1}+$ one hand weeding. Higher number of grains per spike (57.9), 1000-grain weight $\left(39.4 \mathrm{~g} \mathrm{ha}^{-1}\right)$, grain yield $\left(3635.6 \mathrm{~kg} \mathrm{ha}^{-1}\right)$, biological yield $\left(9004 \mathrm{kgha}^{-1}\right)$, and harvest index $(40.23 \%)$ were recorded with the application of clodinafop-propargyl $6 \%+$ fluroxypyr $12 \%$ at $1 \mathrm{~kg} \mathrm{ha}^{-1}+$ one hand weeding 30 days after chemical application, next to weed-free check. Managing weeds with the application of clodinafop-propargyl $6 \%+$ fluroxypyr $12 \%$ at $1 \mathrm{~kg} \mathrm{ha}^{-1}+\mathrm{one} \mathrm{hand}$ weeding contributed maximum (50,745.2 ETB) net benefit. The application of clodinafop-propargyl $6 \%+$ fluroxypyr $12 \%$ at $1.0 \mathrm{~kg} \mathrm{ha}^{-1}$ plus one hand weeding can be recommended to acquire high grain yield of wheat and high economic return in the study site.
\end{abstract}

\section{Introduction}

Wheat is one of the most important food crops with regard to the area and volume of production since it is ranked the $3^{\text {rd }}$ place succeeding to Zea mays and Eragrostis tef in percentage of production. Wheat production in Ethiopia is estimated on 1.7 million hectares and with more than 4.54 million tons; the country is the largest wheat producer in sub-Saharan Africa [1]. However, in Ethiopia, the introduction of wheat productivity has increased and wheat areas covered by the improved varieties are about $70 \%[2]$; the average national productivity is up to $2.68 \mathrm{tha}^{-1}$ [1] in contrast to the research field yields of wheat over $6 \mathrm{tha}^{-1}$ [3]. This shows the presence of the existing gap between potential yield and yield at farmers' level. In Southwestern Ethiopia, wheat is the third major crop following maize and root crops and ranks the second in cereals next to maize as regarding production. In this region, about 127,211 hectares of land is covered by wheat with a productivity of $3,287,591 \mathrm{qt}$, and the most contributors of production of 
wheat in the region are Haddiya $(1,028,947 \mathrm{qt})$, Siltie $(666,143 \mathrm{qt}), \quad$ Kambata-Tambaro $\quad(352,937 \mathrm{qt})$, Kaffa $(135,734 \mathrm{qt})$, and Gamo-Gofa (105,510 qt) zones with a total average production of $27.75 \mathrm{qtha}^{-1}, \quad 28.51 \mathrm{qtha}^{-1}$, $27.00 \mathrm{qtha}^{-1}, 19.00 \mathrm{qtha}^{-1}$, and $15.16 \mathrm{qtha}^{-1}$, respectively [1].

The low average productivity which is below potential yield is because of the frequent abiotic and biotic stresses that are prevailing during critical growth stages of the crop [2]. Among the most prevailing biotic stresses, weed incidence is the primary bottleneck in crop production in general and wheat production in particular in Ethiopia, especially during the rainy season. Weeds are tough to control than some other pests due to the fact they are stationary, and competition usually does no longer end result from just one species. Useful species generally cannot be used to control or restrict weed populations [4]. The heavy rainfall encourages rapid and sufficient increase of weeds, and consequently, all agricultural crops are intently infested with weeds in Southwest Ethiopia [5]. Farmers within the country are aware of weed hassle in their fields; however, often they cannot cope up with heavy weed infestation in the course of the peak period of agricultural activities. Subsequently, most of their fields are weeded late or left unweeded; this is because of manual labor shortage [5]. Bekele et al. [6] stated that such unproductive weed control must be taken into consideration as the principal component for low common yield of wheat resulting in an average annual yield lack of $35 \%$.

Effective weed management practices are the most important practice to meet this challenge. The determination may vary along with ontogeny of the weed, infestation level, environmental condition, and management objectives. Chemical, physical (manual and mechanical), and integrated weed management methods are among the weed management practices used in many cropping systems in Ethiopia. Uses of herbicides are the most important weed management method [7]. In the middle of manual weed management strategies, hand weeding and hoeing can lessen weed emergence as much as $80 \%$, ensuring in a $69 \%$ increase in wheat yield [8]. A shift in the weed population toward a difficult to control species will occur when one control method is used continuously. Integrated weed management relies on the management activities that have proved to be suitable for long-term weed control by amalgamating the use of physical, crop husbandry, biological, and chemical means based on ecological approaches [9] that will prevent weed prolific seed production and germination, promote weed seed bank depletion, and minimize weeds' competitive ability with the crop. The authors of [10] stated that these practices are an important constituent of the crop production activity.

For sustainable weed control program, adopting hand weeding and herbicide application techniques may be an effective and economic weed control strategy. However, for wheat production, there were no confined studies that assessed the herbicide utility and hand weeding in the study areas. Therefore, the current study was instigated to assess the effect of herbicidal and hand weeding control practices on weed infestations, yield attributes, and yield of wheat at Kocha kebele in Chena district of Kaffa zone.

\section{Materials and Methods}

2.1. Description of the Experimental Site. The field experiment was conducted at Kocha kebele in Chena Woreda during 2020 main (meher) crop growing season (August to November), which is geographically located between $7^{\circ}$ up to $7^{\circ} 45^{\prime} \mathrm{N}$ latitude and $35^{\circ} 69^{\prime}$ up to $36^{\circ} 06^{\prime} \mathrm{E}$ longitude. The experimental site is located in Chena Woreda, Kaffa Zone, Southwestern Ethiopia. It is about $510 \mathrm{~km}$ away from Addis Ababa [11].

The mean monthly temperature ranges from $14^{\circ} \mathrm{C}$ to $28^{\circ} \mathrm{C}$. The altitude of Woreda ranges from 1000 to 3000 meter above sea level. Woreda receives rainfall year round almost. The experimental site is mainly distinguished with the average annual maximum and minimum rainfall of $1889 \mathrm{~mm}$ and $1379 \mathrm{~mm}$, respectively [11]. This area was selected for the study because it is one of the areas for wheat production among southwestern wheat-producing areas. The selected experimental site was Kocha and is found in Chena district. The dominant crops grown around the experimental sites include wheat, tef, barley, faba bean, and “enset” [11].

2.2. Planting Materials. Since it is well adapted in the agroecology of the study area, bread wheat variety Shorima (ETBW 5483) was used as a test crop for this experiment. The variety was released in the year 2011 by Kulumsa Agricultural Research Centre [12]. This variety was selected based on its adaptability to agroecological zone of the area, productivity, and resistant for disease (Table 1).

2.3. Treatments and Experimental Design. The treatments that were considered in the study include the following:

$$
\begin{aligned}
& T 1=0.5 \mathrm{~kg} \mathrm{ha}^{-1} 2,4-\mathrm{D} \text { amine salt }+ \text { one hand weeding } \\
& \text { (HW) } \\
& T 2=1.0 \mathrm{~kg} \mathrm{ha}^{-1} 2,4-\mathrm{D} \text { amine salt }+ \text { one HW } \\
& \mathrm{T} 3=1.5 \mathrm{~kg} \mathrm{ha}^{-1} 2,4-\mathrm{D} \text { amine salt }+ \text { one HW } \\
& \mathrm{T} 4=0.4 \mathrm{~kg} \mathrm{ha}^{-1} \text { pyroxsulam }+ \text { one HW } \\
& \mathrm{T} 5=0.5 \mathrm{~kg} \mathrm{ha}^{-1} \text { pyroxsulam }+ \text { one HW } \\
& \text { T6 }=0.6 \mathrm{~kg} \mathrm{ha}^{-1} \text { pyroxsulam }+ \text { one HW } \\
& \mathrm{T} 7=0.5 \mathrm{~kg} \mathrm{ha}^{-1} \text { clodinafop-propargyl } 6 \%+\text { fluroxypyr } \\
& 12 \% \text { + one HW } \\
& T 8=0.75 \mathrm{~kg} \mathrm{ha}^{-1} \text { clodinafop-propargyl } 6 \%+\text { fluroxypyr } \\
& 12 \%+\text { one HW } \\
& T 9=1 \mathrm{~kg} \mathrm{ha}^{-1} \text { clodinafop-propargyl } 6 \%+\text { fluroxypyr } \\
& 12 \%+\text { one HW } \\
& \mathrm{T} 10=1 \mathrm{~kg} \mathrm{ha}^{-1} 2,4-\mathrm{D} \text { amine salt } \\
& \mathrm{T} 11=0.75 \mathrm{~kg} \quad \mathrm{ha}^{-1} \quad \text { clodinafop-propargyl } \\
& 6 \%+\text { fluroxypyr } 12 \% \\
& \mathrm{~T} 12=0.5 \mathrm{~kg} \mathrm{ha}^{-1} \text { pyroxsulam } \\
& \text { T13 = two HW } 30 \text { and } 45 \text { days after emergence }
\end{aligned}
$$


TABLE 1: Description of bread wheat variety which was used for experiment.

\begin{tabular}{lccccc}
\hline \multirow{2}{*}{ Name of variety } & \multirow{2}{*}{ Release year } & \multicolumn{2}{c}{ Yield ton ha ha $^{-1}$} & \multirow{2}{*}{ Releasing centre } & \multirow{2}{*}{ Maturity days } \\
& & On farm & On station & Altitude (masl) \\
\hline Shorima & 2011 & $2.3-4.4$ & $4.8-6.0$ & KARC & $125-150$ \\
\hline
\end{tabular}

Source: [12], Crop Variety Register (1995-2013). KARC, Kulumsa Agriculture Research Centre, Ethiopian Institute of Agricultural Research Centre.

T14 = weed-free check

T15 = weedy check (unweeded)

Randomized complete block design (RCBD) with three replications was used to conduct the experiment and fifteen treatments with a total number of 45 plots. The experimental plots received treatments which were assigned randomly. 1.50 meter was the spacing between blocks, and plots were arranged $1.0 \mathrm{~m}$ apart. The size of each plot was $1.6 \mathrm{~m} \times 3 \mathrm{~m}$ $\left(4.8 \mathrm{~m}^{2}\right)$ having eight rows with a $20 \mathrm{~cm}$ row-to-row spacing. One external row from both sides of each plot and $0.5 \mathrm{~m}$ from row length of each side were considered as border making with each net plot size of $2.40 \mathrm{~m}^{2}(1.2 \mathrm{~m} \times 2 \mathrm{~m})$. The length of total experimental area was $60 \mathrm{~m}$, and the width of that was $9.3 \mathrm{~m}$ with a total area of $558 \mathrm{~m}^{2}(60 \mathrm{~m} \times 9.3 \mathrm{~m})$.

2.4. Data Collection. After 30 days of chemical application and about 15 days earlier than the harvesting time, the weed population counting was conducted. The weeds were categorized as broadleaved, grasses, and sedge. The population count was taken with the help of $0.25 \mathrm{~m} \times 0.25 \mathrm{~m}$ quadrat thrown randomly at two locations in each plot and was changed into per $\mathrm{m}^{2}$. The aboveground biomass of weeds was additionally harvested from each quadrat at the time of recording weed population. One by one, the harvested weeds have been placed into paper baggage. The harvested weeds were exposed for solar radiation for three days and then placed in an oven at $65^{\circ} \mathrm{C}$ temperature. Lastly, the dry biomasses of the weeds in each experimental plot were measured.

2.4.1. Phenology and Growth Parameters. Days to 50\% heading (DH): it was recorded by counting the number of days from the date of sowing to the time when the ears or panicles were fully visible or produced head above the sheath of the flag leaf on $50 \%$ of the plants from each net plot. Days to $90 \%$ physiological maturity (DPM): it was recorded by including the number of days from the date of sowing to the time when the grain hardened and becomes dry and brittle in $90 \%$ of the plants in a net plot area. Plant height $(\mathrm{cm})$ : from the net plot area, average height of ten randomly selected plants of each plot was measured in centimeters from the ground or base to the tip of the panicle at maturity.

2.4.2. Yield Attributes and Yields of Wheat. The average total number and productive tillers were counted from $1.0 \mathrm{~m}$ length of two randomly taken samples in each net plot area at harvesting and converted to meter square $\left(\mathrm{m}^{-2}\right)$. The number of grains per spike was taken randomly from 20 spikes from each plot. Thousand grains were counted after threshing at random from each plot, and their weight was measured with a sensitive balance in gram. Grain yield $(\mathrm{kg}$ $\mathrm{ha}^{-1}$ ): grain yield was measured by taking the weight of the grains threshed from the net plot area of each plot and converted to kilograms per hectare after adjusting the grain moisture content to $12.5 \%$. Aboveground dry biomass $(\mathrm{kg}$ $\left.\mathrm{ha}^{-1}\right)$ : total biomass or biological yield was measured in gram by weighting the sun-dried total aboveground plant biomass (straw + grain) from the net plot area of each plot and converted to kilograms per hectare measured at harvest. Harvest index was determined as the grain yield to aboveground dry biomass and expressed as percentage.

2.4.3. Parameters for Weed Management. WCE (weed control efficiency): it is the magnitude of weed reduction due to weed control treatments and is calculated by

$$
\mathrm{WCE}=\frac{(\mathrm{WDC}-\mathrm{WDT})}{\mathrm{WDC}} \times 100,
$$

where WCE denotes weed control efficiency, WDC denotes weed dry matter in weedy check, and WDT denotes weed dry matter in a particular treatment.

WI (weed index): it is the magnitude of yield reduction due to the presence of weeds in comparison with weed-free check and is calculated as

$$
\mathbf{W I}=\left(\frac{\mathbf{X}-\mathbf{Y}}{\mathbf{X}}\right) \times 100,
$$

where WI denotes weed index, $X$ represents yield in complete weed free, and $Y$ represents yield in a particular treatment.

HEI (herbicide efficiency index): it is herbicide (Table 2) treatments' weed killing potential and the herbicides' impact on the test crop and is calculated as described by [13] as

$$
H E I=\frac{\mathbf{Y T}-\mathbf{Y C}}{\mathbf{Y C}} \mathbf{x} \mathbf{1 0 0} / \mathbf{W I}=\left(\frac{\mathbf{X}-\mathbf{Y}}{\mathbf{X}}\right) \times 100,
$$

where YT denotes yield from treatment, YC denotes yield from control, WDT denotes weed dry matter in treatment, and WDC denotes weed dry matter in control.

2.5. Partial Budget Analysis. The financial feasibility of weed control strategies was calculated by taking into account the additional input costs (total variable costs) involved and the field gross benefit obtained from different weed control treatments. The variable value also includes the labor cost involved for harvesting, threshing, transportation, and winnowing. The actual yield was adjusted downwards to $10 \%$ of experimental yield to represent the farmer's yield. The prevailing local market price $(17.80 \mathrm{ETB} / \mathrm{kg})$ at the harvest of 
TABLE 2: Explanation of postemergence herbicides used with their respective names.

\begin{tabular}{|c|c|c|}
\hline Common & Trade & Chemical \\
\hline $2,4-\mathrm{D}$ amine salt $86 \% \mathrm{SL}$ & $\begin{array}{l}860 \text { suspended liquid } \\
\text { (power) }\end{array}$ & 2,4-D [2,4-di-chloro-phenoxy-acetic acid] \\
\hline $\begin{array}{l}\text { Clodinafop-propargyl } \\
6 \%+\text { fluroxypyr } 12 \%\end{array}$ & $\begin{array}{l}\text { Top Harvest Dual } \\
180 \text { SC }\end{array}$ & $\begin{array}{l}\text { 4-Amino-3,5-dichloro-6-fluoro-2-pyridyloxy acetic acid prop-2-ynyl (2R)-2-[4- } \\
\text { (5-chloro-3-fluoro-pyridin-2-yl) oxy-phenoxy] propionate }\end{array}$ \\
\hline Pyroxsulam (OD) & Pallas 45 OD & $\begin{array}{l}\mathrm{N} \text {-(5,7-Di-methoxy }[1,2,4] \text { triazolo }[1,5 \text {-a]-pyrimidin-2-yl)-2-methoxy-4- } \\
\text { (trifluoromethyl) pyridine-3-sulfonamide }\end{array}$ \\
\hline
\end{tabular}

wheat was taken to determine gross returns. The net returns were calculated by subtracting the cost of treatment from the gross returns: $\mathrm{RNR}=\mathrm{GR}-\mathrm{VC}$, where $\mathrm{RNR}=$ relative net returns, $\mathrm{GR}=$ gross returns, and $\mathrm{VC}=$ variable cost, as defined by [14], which were used on the yield consequences.

2.6. Statistical Data Analysis. From each experimental treatment, data were collected and were subjected to the analysis of variance using SAS (Statistical Analysis Software) version 9.2 [15]. Mean separation of significant treatments was carried out using the least significant difference (LSD) test at $5 \%$ level of probability [16].

\section{Results and Discussion}

\subsection{Weed Parameters}

3.1.1. Weed Community. Broadleaved, grassy, and sedge weeds infested the experimental field (Table 3 ). As observed in the experimental sites, grass weed community was found to be higher with the application of 2,4-D postemergence herbicide as it failed to control grass weeds. Among broadleaved weeds, Galinsoga parviflora Cav. and Ageratum houstonianum Mill. were found to be maximum, and among grassy weeds, Setaria viridis was most abundantly found, but Cyperus difformis L. was the only Cyperus spp. that was found in the experimental field. Except the perennial weed Cynodon dactylon L., all the weed community life form was annual (Table 3).

3.1.2. Weed Dry Weight. Weed dry weight at 60 DAE: the data exhibited that the mean minimum dry weight of broadleaved weed $\left(6.26 \mathrm{gm}^{-2}\right)$ was attained with the application of clodinafop-propargyl $6 \%+$ fluroxypyr $12 \%$ at $1.0 \mathrm{~kg} \mathrm{ha}^{-1}$ which is statistically different from all of the other treatments (Table 4). This might be due to consequence of activeness of the herbicide to its effective weed controlling ability to have a minimum weed density which ultimately results in lower dry weight of broadleaved weeds to be recorded. In addition, lower weed dry biomass of broadleaved weeds at 60 days after crop emergence was obtained with the use of 2,4-D amine salt at $1.5 \mathrm{~kg} \mathrm{ha}^{-1}$ and pyroxsulam with the rate of $0.6 \mathrm{~kg} \mathrm{ha}^{-1}$ and two hand weeding 30 and 45 days after crop emergence with no statistical variation observed among them. Perusal of the ANOVA also exhibited that there was significant reduction in dry weight of weeds over lower doses in all herbicide applied treatments. Generally, as the rate of herbicides increased, the density of broadleaved weeds decreased in all herbicide treatments resulting in observable reduction in dry biomass. On the other hand, maximum dry weight of broadleaved weed $\left(82.53 \mathrm{gm}^{-2}\right)$ was noted in weedy check treatments. The reason is that, in unweeded treatments, weeds existed in higher density and provided an opportunity to compete more with crop plants for available resources and accumulated the maximum nutrients, resulting in higher dry biomass production. This investigation was in accordance with the result of [17] that stated maximum weed dry biomass in weedy check in groundnut production.

The result revealed that, at 60 days after crop emergence, there was higher decrease in grass weed dry weight with the use of clodinafop-propargyl $6 \%+$ fluroxypyr $12 \%$ and pyroxsulam among their rates as well as hand weeding. This may be in line for that as the rate of herbicide increases, density of weed decreases, ultimately resulting in noteworthy lessening in aboveground dry biomass of weeds. The minimum grass weed dry weight $\left(2.12 \mathrm{gm}^{-2}\right)$ was registered with the usage of clodinafop-propargyl 6\% + fluroxypyr $12 \%$ at $1 \mathrm{~kg} \mathrm{ha}^{-1}$ followed by the application of pyroxsulam at $0.6 \mathrm{~kg} \mathrm{ha}^{-1}$ without significant difference between them. In contrast to this, analysis of data exhibited that the maximum dry weight of grass weed $\left(45.76 \mathrm{gm}^{-2}\right)$ was recorded with the use of 2,4-D amine salt at $0.5 \mathrm{~kg} \mathrm{ha}^{-1}$.

Similar to that of the density, lowest dry weight of sedge (3.89 $\mathrm{gm}^{-2}$ ) was recorded in two hand weeding 30 and 45 days after crop emergence, while the maximum dry weight of sedge $\left(38.83 \mathrm{gm}^{-2}\right)$ was obtained with the treatment of clodinafop-propargyl $6 \%+$ fluroxypyr $12 \%$ at $1 \mathrm{~kg} \mathrm{ha}^{-1}$. The reason is that due to the better control of both grassy and broadleaved weed that reduce weed-weed competition and availability of more space, ion of nutrients, molecule of water, and quantum of light and improved use of available resources by weeds. Therefore late germinating weeds were not suppressed under these less competition, resulting in higher dry weight of sedge.

The impact of different weed control practices on the total weed dry matter weight revealed highly major variance $\left(p^{<} 0.01\right)$ at 60 days after emergence of the crop. At 60 days after the emergence of the crop, the lowest total weed dry weight $\left(18.90 \mathrm{gm}^{-2}\right)$ was registered in two hand weeding 30 and 45 days after emergence that comes after with the application of clodinafop-propargyl $6 \%+$ fluroxypyr $12 \%$ at $1 \mathrm{~kg} \mathrm{ha}^{-1}$ with statistical variation among them. This minimum total weed dry biomass in plots treated with two hand weeding is plausible that removing all weed population by manual weeding resulting in minimum weed density, and weeds that emerged after second hand weeding were short in 
TABLE 3: Weed community recorded in wheat field at the experimental sites in 2020 main cropping season.

\begin{tabular}{|c|c|}
\hline Family & Weed species \\
\hline Acanthaceae & Dyschoriste depressa Nees \\
\hline Asteraceae & Ageratum houstonianum mill., Bidens pilosa L., Emilia sonchifolia L., Galinsoga parviflora cav. \\
\hline Chenopodiaceae & Chenopodium album $L$. \\
\hline Commelinaceae & Commelina benghalensis $L$. \\
\hline Cyperaceae & Cyperus difformis $L$. \\
\hline Poaceae & $\begin{array}{c}\text { Avena fatua L., Avena ludoviciana L., Brachiaria reptans Gard. and Hubb., Cynodon dactylon L., Digitaria abyssinica L., } \\
\text { Digitaria sanguinalis L., Eleusine indica L., Lolium temulentum L., Setaria viridis L. }\end{array}$ \\
\hline hyllaceae & Spergula arvensis $L$. \\
\hline Rubiaceae & Galium aparine L. \\
\hline
\end{tabular}

TABLE 4: Effect of weed control practices on weed dry biomass weight $\left(\mathrm{m}^{-2}\right)$ in 2020 main cropping season.

\begin{tabular}{|c|c|c|c|c|c|c|c|c|}
\hline \multirow{2}{*}{ Weed management practices } & \multicolumn{4}{|c|}{60 days after crop emergence } & \multicolumn{4}{|c|}{ At harvest } \\
\hline & Broadleaf & Grass & Sedge & Total & Broadleaf & Grass & Sedge & Total \\
\hline $.5 \mathrm{~kg} \mathrm{ha}^{-1} 2,4-\mathrm{D}$ amine salt + one $\mathrm{HW}$ & $57.98^{\mathrm{b}}$ & $33.38^{\mathrm{a}}$ & $36.37^{\mathrm{bcd}}$ & $127.73^{\mathrm{b}}$ & $69.12^{\mathrm{c}}$ & $14.66^{\mathrm{e}}$ & $16.05^{\mathrm{e}}$ & $99.83^{\mathrm{f}}$ \\
\hline $1 \mathrm{~kg} \mathrm{ha}^{-1} 2,4-\mathrm{D}$ amine salt + one $\mathrm{HW}$ & $49.45^{\mathrm{c}}$ & $33.26^{\mathrm{a}}$ & & $121.55^{\mathrm{c}}$ & & $18.49^{\mathrm{e}}$ & $16.06^{\mathrm{e}}$ & $66.96^{\mathrm{g}}$ \\
\hline $1.5 \mathrm{~kg} \mathrm{ha}^{-1} 2,4-\mathrm{D}$ amine salt + one HW & $10.19^{\mathrm{f}}$ & $32.13^{\mathrm{a}}$ & $33.88^{\mathrm{e}}$ & $76.2^{\mathrm{e}}$ & $16.67^{\mathrm{fg}}$ & $17.85^{\mathrm{e}}$ & $10.51^{\mathrm{g}}$ & $45.03^{\mathrm{i}}$ \\
\hline $0.4 \mathrm{~kg} \mathrm{ha}^{-1}$ pyroxsulam + one HW & $23.33^{\mathrm{d}}$ & $11.24^{\mathrm{c}}$ & $35.29^{\text {cde }}$ & $69.86^{\mathrm{f}}$ & $32.01^{\mathrm{de}}$ & $6.01^{\mathrm{f}}$ & $23.95^{\mathrm{d}}$ & $61.97^{\text {gh }}$ \\
\hline $0.5 \mathrm{~kg} \mathrm{ha}^{-1}$ pyroxsulam + one $\mathrm{HW}$ & $16.47^{\mathrm{e}}$ & $4.58^{\mathrm{de}}$ & $37.55^{\mathrm{abc}}$ & $58.6^{\mathrm{g}}$ & $19.73^{\mathrm{f}}$ & $4.12^{\mathrm{fg}}$ & $12.75^{\mathrm{fg}}$ & $36.6^{j}$ \\
\hline $0.6 \mathrm{~kg} \mathrm{ha}^{-1}$ pyroxsulam + one $\mathrm{HW}$ & $11.49^{\mathrm{f}}$ & $2.12^{\mathrm{f}}$ & $38.83^{\mathrm{a}}$ & $51.67^{\mathrm{i}}$ & $14.29^{\mathrm{g}}$ & $4^{\mathrm{fg}}$ & $13.6^{\mathrm{ef}}$ & $31.89^{\mathrm{jk}}$ \\
\hline $\begin{array}{l}0.5 \mathrm{~kg} \mathrm{ha}^{-1} \text { clodinafop-propargyl } 6 \%+\text { fluroxypyr } 12 \%+\text { one } \\
\text { HW }\end{array}$ & $21.35^{\mathrm{d}}$ & & 34 & & & $2^{1}$ & $21.6^{\mathrm{d}}$ & $7^{\mathrm{h}}$ \\
\hline $\begin{array}{l}0.75 \mathrm{~kg} \mathrm{ha}^{-1} \text { clodinafop-propargyl } 6 \%+\text { fluroxypyr } 12 \%+\text { one } \\
\text { HW }\end{array}$ & & & abc & gh & & $4.73^{\mathrm{fg}}$ & $12.93^{\mathrm{f} 8}$ & $30.94^{\mathrm{jk}}$ \\
\hline $\begin{array}{l}1 \mathrm{~kg} \mathrm{ha}^{-1} \text { clodinafop-propargyl } 6 \%+\text { fluroxypyr } 12 \%+\text { one } \\
\text { HW }\end{array}$ & $6.26^{\mathrm{g}}$ & $2.89^{\mathrm{er}}$ & $5.99^{\mathrm{b}-\mathrm{e}}$ & $45.14^{\mathrm{j}}$ & 11 & $4.32^{\mathrm{fg}}$ & $12.37^{\mathrm{fg}}$ & $28.59^{\mathrm{k}}$ \\
\hline $1 \mathrm{~kg} \mathrm{ha}^{-1} 2,4-\mathrm{D}$ amine $\mathrm{s}$ & & & $35.69^{\mathrm{b}-\mathrm{e}}$ & & & & & $238.88^{\mathrm{b}}$ \\
\hline $0.75 \mathrm{~kg} \mathrm{ha}^{-1}$ clodinafop-prop & $15.47^{\mathrm{e}}$ & $4.34^{\mathrm{de}}$ & $36.43^{\mathrm{bc}}$ & $56.25^{\mathrm{gh}}$ & $95.47^{\mathrm{b}}$ & $36.73^{c}$ & $61.85^{\mathrm{a}}$ & $194.05^{\mathrm{c}}$ \\
\hline $0.5 \mathrm{~kg} \mathrm{ha}^{-1}$ pyroxsulam & $12.92^{\text {ef }}$ & $5.24^{\mathrm{d}}$ & $35.92^{\mathrm{b}-\mathrm{e}}$ & $54.09^{\mathrm{hi}}$ & $64.9^{c}$ & $31.41^{\mathrm{d}}$ & $39.15^{\mathrm{c}}$ & $135.47^{\mathrm{d}}$ \\
\hline 30 and 45 days & $11.11^{\mathrm{f}}$ & $3.9^{\mathrm{def}}$ & $3.89^{\mathrm{f}}$ & $18.9^{\mathrm{k}}$ & $33.87^{\mathrm{d}}$ & $29.44^{\mathrm{d}}$ & $48.59^{\mathrm{b}}$ & $111.89^{\mathrm{e}}$ \\
\hline & $0^{\mathrm{h}}$ & $0^{\mathrm{g}}$ & $0^{\mathrm{g}}$ & $0^{1}$ & $0^{\mathrm{h}}$ & $0^{\mathrm{g}}$ & $0^{\mathrm{h}}$ & $0^{1}$ \\
\hline eck (u & $82.53^{\mathrm{a}}$ & $29.43^{\mathrm{b}}$ & $37.44^{\mathrm{abc}}$ & $149.4^{\mathrm{a}}$ & $261.87^{\mathrm{a}}$ & $105.44^{\mathrm{b}}$ & $59.68^{\mathrm{a}}$ & $426.98^{\mathrm{a}}$ \\
\hline LSI & & & & 4.35 & 5.08 & 4.54 & 2.87 & 7.98 \\
\hline CV (\%) & 11.96 & 10.37 & 8.47 & 7.66 & 9.26 & 12.31 & 9.46 & 4.57 \\
\hline
\end{tabular}

Same letters indicate means not significantly different at $5 \%$ level of significance. CV, coefficient of variation; LSD, least significant difference; HW, hand weeding.

growth and have less biomass accumulation at 60 days after crop emergence in case of low total dry weight of weeds. The result was in line with the result of Wajeeh et al. [18] who indicated that although manual weed control methods (pulling weeds by hand) are tedious and weather dependent, it is the most effective and safest method.

Furthermore, perusal of the ANOVA indicated that there was high decrease in total weed dry weight due to herbicide application over their lower doses after 30 days of their application as negative influence on physiology of susceptible weeds increases due to herbicide rate increment. The result showed that the mean minimum total dry biomass of weed $\left(45.14 \mathrm{gm}^{-2}\right)$, next to two hand weeding 30 and 45 days after the emergence of the crop, was recorded with the application of clodinafop-propargyl $6 \%+$ fluroxypyr $12 \%$ at $1.0 \mathrm{~kg} \mathrm{ha}^{-1}$ which was statistically different from all other herbicide-treated plots.

Overall comparison of herbicide treatments indicated that there was higher decline of total weed dry biomass with the use of pyroxsulam and clodinafop-propargyl
$6 \%+$ fluroxypyr $12 \%$ than $2,4-\mathrm{D}$ amine salt 30 days after their application. This important loss of total weed dry biomass weight may possibly be due to effectiveness of these herbicides to lower both grassy and broadleaved weeds' total dry weight compared with 2,4-D amine salt. The current result is in line with the outcome of Singh et al. [19] who stated that pyroxsulam is a broad-spectrum herbicide which controls grassy as well as broadleaved weeds in wheat. In contrast to this, the highest total weed dry biomass weight $\left(149.4 \mathrm{gm}^{-2}\right)$ was recorded in weedy check treatments and it was considerably different from other treatments in this experiment. Relatively more weed dry biomass weight in weedy check may perhaps be due to the presence of weed density as well as more competition of weeds with crop for the same ion nutrients, volume of space, quantum of light, and molecules of water resulting in higher biomass production. The result was harmonized with the study of Sareta et al. [20] who described that the highest dry weed mass was noted in weedy check treatment. 
Weed dry weight at harvest: at this stage, lowest weed dry biomass weight of broadleaved weed $\left(11.9 \mathrm{gm}^{-2}\right)$ was verified with the application of clodinafop-propargyl $6 \%+$ fluroxypyr $12 \%$ at $1 \mathrm{~kg} \mathrm{ha}^{-1}+$ one hand weeding followed by the usage of pyroxsulam at $0.5 \mathrm{kgha}^{-1}$ and pyroxsulam at $0.6 \mathrm{~kg} \mathrm{ha}^{-1}+$ one hand weeding which were supplemented with one hand weeding with no statistical difference between them (Table 4). The application of clodinafop-propargyl $6 \%+$ fluroxypyr $12 \%$ at $0.5 \mathrm{~kg} \mathrm{ha}^{-1}$ and 2,4-D amine salt at $1.0 \mathrm{~kg} \mathrm{ha}^{-1}$ supplemented with one and two hand weeding 30 and 45 days after crop emergence was statistically in parity regarding broadleaved weed dry weight at harvest. The analyzed data also exhibited that there was substantial decrease in broadleaved weed dry matter weight in all herbicide-treated plots with one hand weeding supplementation, but no statistical difference was observed with usage of pyroxsulam at 0.5 and $0.6 \mathrm{~kg} \mathrm{ha}^{-1}$ combined with one hand weeding. Moreover, in the integrated treatments, lower broadleaved weed dry weight was recorded as compared to their sole application in both herbicides used. These may perhaps be due to control of weeds by herbicide application and removing latter emerged and tolerant weeds through hand weeding resulting in minimum weed density and later growing weeds (after hand weeding) accumulated less biomass production, ultimately resulting minimum weed dry biomass weight. The outcome was in accordance with the finding of Raize et al. [21] who informed proper use of postemergence herbicides or other weeding techniques, especially hand weeding at tillering stage drops the weed dry weight as matched with herbicides used alone or weedy check treatments.

On the other hand, maximum broadleaved weed dry biomass weight $\left(261.87 \mathrm{gm}^{-2}\right)$ was recorded in weedy check treatments and it was considerably better than other weed control practices. This greater weed dry weight may well be due to better weed density per meter square, high growth, and maximum dry matter accumulation resulting maximum weed dry weight at harvest. The current effect was in accordance with the inquiry of [22] which described that the weeds sprouted first with the crop have got an advantage to accumulate more dry matter.

Similar to dry weight of broadleaved weed, the lower grass weed dry weight was documented with integrated approach than sole application. This possibly will be due to removal of weeds at the initial time by herbicide usage and latter weeds through hand weeding resulting in minimum weed density and later growing weeds accumulated less dry biomass weight, ultimately resulting minimum outcome. The effect was in line with the verdict of Mekonnen et al. [23] who identified that, at 55 days after emergence, weeds accumulated appreciably the lowest dry weight in plots treated with $1 \mathrm{~kg} \mathrm{ha}^{-1}$ of metolachlor and pendimethalin with one hand weeding supplementation which may possibly be due to the integrated effect of herbicides and hand weeding practices in cowpea.

Furthermore, the statistical analysis of the variance exhibited that minimum grass weed dry biomass was observed from clodinafop-propargyl $6 \%+$ fluroxypyr $12 \%$ at 0.75 and $1 \mathrm{~kg} \mathrm{ha}^{-1}$ and pyroxsulam at 0.5 and $0.6 \mathrm{~kg} \mathrm{ha}^{-1}$, in combination with one hand weeding 30 days after chemical application, which was statistically equal. Although statistically equal, application of clodinafop-propargyl $6 \%+$ fluroxypyr $12 \%$ and pyroxsulam supplemented with one hand weeding showed reduction on dry weight of grass over their lower rates.

Rather, maximum grass weed dry weight $\left(112.11 \mathrm{gm}^{-2}\right)$ was noted down with the application of 2,4-D at $1.0 \mathrm{~kg} \mathrm{ha}^{-1}$ which was statistically different from all other treatments including weedy check at harvest. This maximum dry weight over other treatments might be due to the usage of 2,4-D amine salt that only controls broadleaved weeds in case having higher density which have maximum dry weight, in comparison with that of weedy check. This might be due to controlling broadleaved weeds by 2,4-D herbicide, provided an opportunity to grassy weeds to obtain available resources in larger amount due to reduction in competition, ultimately resulting in maximum dry weight accumulation.

The data inquiry of the variance showed that the minimum weight of sedge biomass $\left(10.51 \mathrm{gm}^{-2}\right)$ was recorded with the usage of $2,4-\mathrm{D}$ at $1.5 \mathrm{~kg} \mathrm{ha}^{-1}+$ one hand weeding followed by the application of pyroxsulam at $0.6 \mathrm{~kg} \mathrm{ha}^{-1}$, clodinafop-propargyl $6 \%+$ fluroxypyr $12 \%$ at $0.75 \mathrm{~kg} \mathrm{ha}^{-1}$, and pyroxsulam at $0.5 \mathrm{~kg} \mathrm{ha}^{-1}$, in combination with one hand weeding with no statistical difference (Table 4). However, the maximum dry weight of sedge $\left(61.85 \mathrm{gm}^{-2}\right)$ was recorded with the application of clodinafop-propargyl $6 \%+$ fluroxypyr $12 \%$ at $0.75 \mathrm{~kg} \mathrm{ha}^{-1}$ keeping an eye on with weedy check plots with statistical in parity.

The data pertaining to total weed dry matter weight were considerably obstructed by different experimental treatments at harvest. The result revealed that the lowest total weed dry matter weight $\left(28.59 \mathrm{gm}^{-2}\right)$ was obtained with the application of clodinafop-propargyl $6 \%+$ fluroxypyr $12 \%$ at $1 \mathrm{~kg} \mathrm{ha}^{-1}+$ one hand weeding followed by the application of pyroxsulam at $0.5 \mathrm{~kg} \mathrm{ha}^{-1}$ and pyroxsulam at $0.6 \mathrm{~kg} \mathrm{ha}^{-1}$, supplemented with one hand weeding with statistical in parity. Moreover, the data with respect to total weed dry matter weight indicated that there was significant reduction with application of pyroxsulam and clodinafop-propargyl $6 \%+$ fluroxypyr $12 \%$ as compared to $2,4-\mathrm{D}$ amine salt with each respective dose. It is inevitable that control of both grass and broadleaved weeds by these two chemicals reduces weed density resulting in lower dry biomass. The end result of the study was in line with the finding of Iqbal [24] who confirmed that the weed dry biomass reduced based on spectrum of action of herbicides used.

Perusal of ANOVA indicated that there was substantial decrease in total weed dry biomass weight with the use of herbicides in amalgamation with one hand weeding 30 days after chemical application as associated to their sole use. This might be due to management of weeds that emerged together with crops by herbicide application initially and removal of latter weeds through hand weeding resulting in minimum weed density and also later growing weeds accumulated less dry weight, ultimately resulting in minimum dry weight. The study was in harmony with the finding of Pisal and Sagarka [25] who said application of pre-emergence herbicide called pendimethalin at $0.9 \mathrm{~kg} \mathrm{ha}^{-1}+$ one 
hand weeding at 40 days after sowing evidenced higher to the remaining of the treatments by resulting in minimum weed dry weight and higher weed control efficiency in wheat. However, maximum total dry biomass of weeds $\left(426.98 \mathrm{gm}^{-2}\right)$ at harvest was recorded in unweeded plots and it was significantly different from other treatments. This greater outcome might be due to weed density per meter square and more competition for the same ion nutrients, space, quantum of light, and molecule of water resulting in higher weed biomass production. This result is in agreement with the study of Mandal et al. [26] who reported that maximum weed biomass was found from control (no weeding) in wheat.

3.1.3. Parameters for Weed Control. Weed control efficiency: the highest weed control efficiency $(93.30 \%)$ was recorded with the application of clodinafop-propargyl $6 \%+$ fluroxypyr $12 \%$ at $1 \mathrm{~kg} \mathrm{ha}^{-1}+$ one hand weeding following the weed-free treatment (Table 5). The application of herbicides supplemented with one hand weeding as compared to their sole application was also recorded to have greater weed control efficiency. This may possibly be due to effective weed control with the application of herbicides at early growth stage and removing both tolerant and late emerging weeds by hand weeding which resulted in low weed counts and finally reduced the total dry weight of weeds at harvest. A similar result was obtained by the authors of [27] who resolved that the use of pendimethalin at $1.0 \mathrm{~kg} \mathrm{ha}^{-1}+$ one hand weeding extraordinarily reduced the weed dry biomass which caused increase in weed control efficiency in wheat.

In addition, greater efficiency of weed control was verified in treatments of pyroxsulam and clodinafoppropargyl $6 \%$ + fluroxypyr $12 \%$ than $2,4-\mathrm{D}$ amine salt with each respective dose. This is because use of herbicides controls both grass and broadleaf weeds. This outcome is in agreement with the analysis of Raghavaiah and Zeki [28] who indicated that weed control efficiency was higher with the usage of isoproturon (broad-spectrum herbicide) at $1.50 \mathrm{~kg} \mathrm{ha}^{-1}$ in wheat.

Weed index: the result discovered that weed index became statistically the uppermost (68.59\%) in weedy plots than the rest of all treated plots. This may possibly be due to the maximum weed density recorded in unweeded plots so that there is highest competition for the same quantum of sunlight, moisture, and ion nutrients and less free space available for growth, bringing reduction in yield attributes which resulted in the highest decrease in yield due to incidence of weeds in contrast with weed-free checks (Table 5). The investigation was nearly in accordance with the finding of Raghavaiah and Zeki [28] who stated that $72 \%$ of wheat yield reduction was noted due to uncontrolled weed growth throughout the crop growth period. On the other hand, significantly, the lowest weed index $(14.18 \%)$ was noted with the application of clodinafop-propargyl $6 \%+$ fluroxypyr $12 \%$ at $1 \mathrm{~kg} \mathrm{ha}^{-1}+$ one hand weeding among the weed management practices which was statistically similar with two hand weeding 30 and 45 days after crop emergence, application of clodinafop-propargyl $6 \%+$ fluroxypyr $12 \%$ at $0.75 \mathrm{~kg} \mathrm{ha}^{-1}+$ one hand weeding, application of pyroxsulam at $0.5 \mathrm{~kg} \mathrm{ha}^{-1}+$ one hand weeding, and application pyroxsulam at $0.6 \mathrm{~kg} \mathrm{ha}^{-1}+$ one hand weeding.

Furthermore, statistical evaluation of the variance exhibited that within the integrated application of chemicals with one hand weeding, lower weed index was recorded as compared to their sole application and unweeded plots. This could be due to the application of herbicides for control of early emerged weeds, and late emerged weeds was controlled through hand weeding, which reduces weed competition among crops bringing higher grain yield, ultimately resulting low weed index. This current investigation was in agreement with the outcome of Kumar et al. [29] who indicated that a logical aggregate of several weed control methods is likely to prove the most actual method to get effective control of composite weed flora.

Herbicide efficiency index: numerical inquiry of the data showed that the highest herbicide efficiency index (27.06\%) was verified in plots treated with clodinafop-propargyl $6 \%$ + fluroxypyr $12 \%$ at $1 \mathrm{~kg} \mathrm{ha}^{-1}+$ one hand weeding followed by the application of clodinafop-propargyl $6 \%+$ fluroxypyr $12 \%$ at $0.75 \mathrm{~kg} \mathrm{ha}^{-1}$, pyroxsulam at $0.5 \mathrm{~kg} \mathrm{ha}^{-1}$, and pyroxsulam at $0.6 \mathrm{~kg} \mathrm{ha}^{-1}$ supplemented with one hand weeding with no statistical difference observed in between (Table 5). The analyzed data indicated that, as the rate increases, herbicide efficiency index increases. This might be because as herbicide rate increases, weed control efficiency increases so that there is reduction in weed density and dry biomass accumulation at harvest to obtain considerable yield, ultimately resulting in higher herbicide efficiency index. The result was in accordance with the finding of Mirza et al. [30] who revealed that the herbicide efficiency index was increased when the rates of herbicides increased due to better efficiency of weed control and lower weed index.

\subsection{Crop}

3.2.1. Phenology and Growth. Days to 50\% heading: the longest time (65.33 days) until 50\% heading, next to weedfree check (65.67 days), was observed with the application of clodinafop-propargyl $6 \%$ + fluroxypyr $12 \%$ at $1 \mathrm{~kg} \mathrm{ha}^{-1}+$ one hand weeding followed by two hand weeding 30 and 45 days after crop emergence, but not statistically different (Table 6). This may perhaps be due to actual control of weeds by these treatments that reduced density of weeds so that weed competition for available resources become less which allowed more period for a crop to stay in vegetative growth, ultimately resulting in longer period to reach $50 \%$ heading. This result is in line with the finding of Sunday and Ekea [31] who identified that the synergic influences of fertilizers in stimulation of cell division enhancement, cell growth promotion, and vegetative growth were prolonged for reasonably longer period owing to ample supplies of macronutrients and possibly other micronutrients in rice.

In contrast to this, statistical analysis of the variance indicated that the shortest time (62.00 days) required for 
TABLE 5: Effect of weed control treatments on parameters for weed control in 2020 main cropping season.

\begin{tabular}{|c|c|c|c|}
\hline Treatments & WCE $(\%)$ & WI $(\%)$ & HEI (\%) \\
\hline $0.5 \mathrm{~kg} \mathrm{ha}^{-1} 2,4-\mathrm{D}$ amine salt + one $\mathrm{HW}$ & $76.60^{\mathrm{g}}$ & $48.8^{\mathrm{bc}}$ & $2.78^{\text {cde }}$ \\
\hline $1 \mathrm{~kg} \mathrm{ha}^{-1} 2,4-\mathrm{D}$ amine salt + one $\mathrm{HW}$ & $84.30^{\mathrm{f}}$ & $40.79^{\mathrm{bcd}}$ & $6.00^{\text {bcde }}$ \\
\hline $1.5 \mathrm{~kg} \mathrm{ha}^{-1} 2,4-\mathrm{D}$ amine salt + one HW & $89.43^{\mathrm{d}}$ & $31.05^{\mathrm{de}}$ & $11.64^{\mathrm{b}}$ \\
\hline $0.4 \mathrm{~kg} \mathrm{ha}^{-1}$ pyroxsulam + one $\mathrm{HW}$ & $85.50^{\mathrm{f}}$ & $35.11^{\text {de }}$ & $7.73^{\mathrm{bcd}}$ \\
\hline $0.5 \mathrm{~kg} \mathrm{ha}^{-1}$ pyroxsulam + one $\mathrm{HW}$ & $91.40^{\mathrm{c}}$ & $16.56^{\mathrm{f}}$ & $20.09^{\mathrm{a}}$ \\
\hline $0.6 \mathrm{~kg} \mathrm{ha}^{-1}$ pyroxsulam + one $\mathrm{HW}$ & $92.53^{\mathrm{bc}}$ & $23.25^{\mathrm{ef}}$ & $20.35^{\mathrm{a}}$ \\
\hline $0.5 \mathrm{~kg} \mathrm{ha}^{-1}$ clodinafop-propargyl $6 \%+$ fluroxypyr $12 \%+$ one $\mathrm{HW}$ & $87.00^{\mathrm{e}}$ & $36.61^{\mathrm{cd}}$ & $8.38^{\mathrm{bc}}$ \\
\hline $0.75 \mathrm{~kg} \mathrm{ha}^{-1}$ clodinafop-propargyl $6 \%+$ fluroxypyr $12 \%+$ one HW & $92.75^{\mathrm{bc}}$ & $17.69^{\mathrm{f}}$ & $23.22^{\mathrm{a}}$ \\
\hline $1 \mathrm{~kg} \mathrm{ha}^{-1}$ clodinafop-propargyl $6 \%+$ fluroxypyr $12 \%+$ one HW & $93.30^{\mathrm{b}}$ & $14.18^{\mathrm{f}}$ & $27.06^{\mathrm{a}}$ \\
\hline $1 \mathrm{~kg} \mathrm{ha}^{-1} 2,4-\mathrm{D}$ amine salt & $44.03^{\mathrm{k}}$ & $51.63^{\mathrm{b}}$ & $0.98^{\mathrm{de}}$ \\
\hline $0.75 \mathrm{~kg} \mathrm{ha}^{-1}$ clodinafop-propargyl $6 \%+$ fluroxypyr $12 \%$ & $54.53^{\mathrm{j}}$ & $32.57^{\text {de }}$ & $2.58^{\text {cde }}$ \\
\hline $0.5 \mathrm{~kg} \mathrm{ha}^{-1}$ pyroxsulam & $68.20^{\mathrm{i}}$ & $32.45^{\mathrm{de}}$ & $3.67^{\text {cde }}$ \\
\hline Two HW 30 and 45 days after emergence & $73.80^{\mathrm{h}}$ & $16.28^{\mathrm{f}}$ & - \\
\hline Weed-free check & $100^{\mathrm{a}}$ & - & - \\
\hline Weedy check (unweeded) & - & $68.59^{\mathrm{a}}$ & - \\
\hline LSD (5\%) & 1.46 & 12.68 & 6.99 \\
\hline CV (\%) & 1.16 & 24.44 & 14.23 \\
\hline
\end{tabular}

Approach observed by using the identical letter is not notably one of a kind at $5 \%$ level of significance. CV, coefficient of variation; LSD, least significance difference; HW, hand weeding; WI, weed index; HEI, herbicide efficiency index; WCE, weed control efficiency.

$50 \%$ heading was observed in weed check plots. This earlier time that is required for $50 \%$ heading might be because plots with highest weed density had continuous antagonism for the same ion of nutrients, molecule of water, air, and volume of space so that plants in condition where resource limitation exists grow faster to compensate this limitation and complete its $50 \%$ heading at earlier time.

Days to $90 \%$ maturity: the inquiry of result showed that the application of different weed management practices significantly affects days of $90 \%$ physiological maturity of the crop. The result indicated that the delayed maturity (109.00 days) was observed at weed-free plot followed by two hand weeding at 30 and 45 days after emergence and use of clodinafop-propargyl $6 \%$ + fluroxypyr $12 \%$ at $1 \mathrm{~kg} \mathrm{ha}^{-1}+$ one hand weeding, respectively, nonetheless they are statistically similar (Table 6). This delayed maturity of a crop might be due to that effective control of the weeds by these treatments and also fewer struggle for moisture, quantum of light, and ion of nutrients and more free space owing to better utilization of resources as a consequence of less weed antagonism so that crops stay more in vegetative growth which ultimately resulted into significant increase of $90 \%$ physiological maturity. The result was in contradiction with the analysis of Sunday and Ekea [31] who quantified that giving plots with herbicides and complementing with hand weeding at intervals helped to reduce the number of days to maturity. On the other hand, statistical analysis of the data indicated that the earliest time to reach physiological maturity (101 days) of a crop was found at weedy plots. This can be due to that uncontrolled weed growth led to considerable increment in completion for available resources so that resource limitation exists and plants grow faster to compensate this resource limitation and complete its physiological maturity at earlier time.

Plant height: the data inquiry revealed that different weed control practices had a substantial influence on plant height. Plants attained maximum height $(88.37 \mathrm{~cm})$ in weedy check plots which was statistically similar with the use of 2,4$\mathrm{D}$ amine salt at $1.0 \mathrm{~kg} \mathrm{ha}^{-1}$ and clodinafop-propargyl $6 \%+$ fluroxypyr $12 \%$ at $0.5 \mathrm{~kg} \mathrm{ha}^{-1}+$ one hand weeding (Table 6). This substantial increase in plant height might be due to the antagonism for quantum of light and volume of space among weeds and enforced the plant growing more. The investigation remained in accordance with the aforementioned verdicts of Muhammad et al. [32] who quantified that the highest plant height $(98.30 \mathrm{~cm})$ was acquired from weedy check, despite the minimum plant height $(81.6 \mathrm{~cm})$ was achieved from weed-free check with no substantial change among two hand weeding 30 and $45 \mathrm{DAE}$ and 2,4-D amine salt at $1.5 \mathrm{~kg} \mathrm{ha}^{-1}+$ one hand weeding.

3.2.2. Yield Components and Yield. Total number and productive tillers $\left(\mathrm{m}^{-2}\right)$ : influence of treatments on total number of tillers per $\mathrm{m}^{-2}$ showed that next to weed-free cheek which registered with $386.3 \mathrm{~m}^{-2}$, the highest total tiller number $\left(358 \mathrm{~m}^{-2}\right)$ was verified at two hand weeding 30 and 45 days after crop emergence followed by the application of clodinafop-propargyl $6 \%+$ fluroxypyr $12 \%$ at $1 \mathrm{~kg} \mathrm{ha}^{-1}+$ one hand weeding $\left(349.3 \mathrm{~m}^{-2}\right)$ without statistical difference (Table 7). This might be due to the early removal of weeds by hand weeding that results in less competition for the same quantum of light, moisture, and ion of nutrients and more free space available for growth of tillers which helped in increasing the number of tillers per plant. The effect was in arrangement with the outcome of Ologbon and Yusuf [8] who stated that two hand weeding gave better efficiency for weed control when compared to the rest of the weed control treatments so as to help in providing sufficient space for tillers' emergence. As indicated by analysis of variance, integration of chemical with hand weeding also bears higher number of tillers than their sole application. On the other hand, the lowest of total number of tillers $\left(248.7 \mathrm{~m}^{-2}\right)$ was obtained in plots treated with 2,4-D amine salt at $1 \mathrm{~kg} \mathrm{ha}^{-1}$ 
TABLE 6: Effect of treatments on phenology and growth of wheat in 2020 main cropping season.

\begin{tabular}{|c|c|c|c|}
\hline Treatments & Days to $50 \%$ heading & Days to $90 \%$ maturity & Plant height $(\mathrm{cm})$ \\
\hline $0.5 \mathrm{~kg} \mathrm{ha}^{-1} 2,4-\mathrm{D}$ amine salt + one $\mathrm{HW}$ & $62.67^{\mathrm{ef}}$ & $103.67^{\mathrm{e}}$ & $85.13^{\mathrm{bcd}}$ \\
\hline $1.0 \mathrm{~kg} \mathrm{ha}^{-1} 2,4-\mathrm{D}$ amine salt + one HW & $63.00^{\mathrm{def}}$ & $104.00^{\text {de }}$ & $83.63^{\mathrm{de}}$ \\
\hline $1.5 \mathrm{~kg} \mathrm{ha}^{-1} 2,4-\mathrm{D}$ amine salt + one HW & $64.00^{\mathrm{a}-\mathrm{e}}$ & $105.67^{\mathrm{bcd}}$ & $82.87^{\mathrm{ef}}$ \\
\hline $0.4 \mathrm{~kg} \mathrm{ha}^{-1}$ pyroxsulam + one $\mathrm{HW}$ & $63.00^{\mathrm{def}}$ & $104.00^{\mathrm{de}}$ & $83.70^{\text {de }}$ \\
\hline $0.5 \mathrm{~kg} \mathrm{ha}^{-1}$ pyroxsulam + one $\mathrm{HW}$ & $64.33^{\mathrm{a}-\mathrm{e}}$ & $106.33^{\mathrm{bc}}$ & $84.87^{\mathrm{cd}}$ \\
\hline $0.6 \mathrm{~kg} \mathrm{ha}^{-1}$ pyroxsulam + one $\mathrm{HW}$ & $63.33^{\mathrm{c}-\mathrm{f}}$ & $105.33^{\text {cde }}$ & $83.70^{\mathrm{de}}$ \\
\hline $0.5 \mathrm{~kg} \mathrm{ha}^{-1}$ clodinafop-propargyl $6 \%+$ fluroxypyr $12 \%+$ one $\mathrm{HW}$ & $63.33^{\mathrm{c}-\mathrm{f}}$ & $104.00^{\mathrm{de}}$ & $86.57^{\mathrm{abc}}$ \\
\hline $0.75 \mathrm{~kg} \mathrm{ha}^{-1}$ clodinafop-propargyl $6 \%+$ fluroxypyr $12 \%+$ one $\mathrm{HW}$ & $64.33^{\mathrm{a}-\mathrm{e}}$ & $106.67^{\mathrm{bc}}$ & $85.20^{\mathrm{bcd}}$ \\
\hline $1.0 \mathrm{~kg} \mathrm{ha}^{-1}$ clodinafop-propargyl $6 \%+$ fluroxypyr $12 \%+$ one HW & $65.33^{\mathrm{ab}}$ & $107.00^{\mathrm{abc}}$ & $83.63^{\mathrm{de}}$ \\
\hline $1.0 \mathrm{~kg} \mathrm{ha}^{-1} 2,4-\mathrm{D}$ amine salt & $63.67^{\mathrm{b}-\mathrm{f}}$ & $103.67^{\mathrm{e}}$ & $86.87^{\mathrm{ab}}$ \\
\hline $0.75 \mathrm{~kg} \mathrm{ha}^{-1}$ clodinafop-propargyl $6 \%+$ fluroxypyr $12 \%$ & $64.67^{\mathrm{a}-\mathrm{d}}$ & $106.67^{\mathrm{bc}}$ & $85.37^{\mathrm{bcd}}$ \\
\hline $0.5 \mathrm{~kg} \mathrm{ha}^{-1}$ pyroxsulam & $63.00^{\mathrm{def}}$ & $105.33^{\text {cde }}$ & $85.01^{\mathrm{cd}}$ \\
\hline Two HW 30 and 45 days after emergence & $65.00^{\mathrm{abc}}$ & $107.33^{\mathrm{ab}}$ & $82.47^{\mathrm{ef}}$ \\
\hline Weed-free check & $65.67^{\mathrm{a}}$ & $109.00^{\mathrm{a}}$ & $81.60^{\mathrm{f}}$ \\
\hline Weedy check (unweeded) & $62.00^{\mathrm{f}}$ & $101.67^{\mathrm{f}}$ & $88.37^{\mathrm{a}}$ \\
\hline LSD (5\%) & 1.74 & 1.75 & 1.83 \\
\hline CV (\%) & 1.63 & 1.09 & 1.31 \\
\hline
\end{tabular}

Same letter: not significantly different. CV, coefficient of variation; LSD, least significant difference; HW, hand weeding.

TABLE 7: Effect of treatments on yield component of wheat in 2020 main cropping season.

\begin{tabular}{|c|c|c|c|c|}
\hline Treatments & $\begin{array}{l}\text { Total no. of tillers } \\
\left(\mathrm{m}^{-2}\right)\end{array}$ & $\begin{array}{c}\text { Productive tillers } \\
\left(\mathrm{m}^{-2}\right)\end{array}$ & $\begin{array}{l}\text { No. of grains } \\
\text { spike }^{-1}\end{array}$ & $\begin{array}{l}\text { 1000-grain weight } \\
(\mathrm{g})\end{array}$ \\
\hline $0.5 \mathrm{~kg} \mathrm{ha}^{-1} 2,4-\mathrm{D}$ amine salt + one $\mathrm{HW}$ & $262.0^{\text {hi }}$ & $227.0^{\mathrm{i}}$ & $38.77^{\mathrm{jk}}$ & $34.27^{\text {hi }}$ \\
\hline $1 \mathrm{~kg} \mathrm{ha}^{-1} 2,4-\mathrm{D}$ amine salt + one $\mathrm{HW}$ & $283.0^{\mathrm{fgh}}$ & $265.0^{\text {fgh }}$ & $39.87^{\mathrm{ij}}$ & $34.32^{\mathrm{h}}$ \\
\hline $1.5 \mathrm{~kg} \mathrm{ha}^{-1} 2,4-\mathrm{D}$ amine salt + one HW & $317.0^{\text {cde }}$ & $282.0^{\mathrm{d}-\mathrm{g}}$ & $47.83^{\mathrm{fg}}$ & $37.11^{\text {ef }}$ \\
\hline $0.4 \mathrm{~kg} \mathrm{ha}^{-1}$ pyroxsulam + one HW & $271.0^{\text {ghi }}$ & $247.7^{\text {hi }}$ & $42.19^{\text {hi }}$ & $35.32^{\text {gh }}$ \\
\hline $0.5 \mathrm{~kg} \mathrm{ha}^{-1}$ pyroxsulam + one $\mathrm{HW}$ & $336.0^{\mathrm{bcd}}$ & $311.0^{\mathrm{bcd}}$ & $54.73^{\mathrm{cd}}$ & $38.06^{\text {cde }}$ \\
\hline $0.6 \mathrm{~kg} \mathrm{ha}^{-1}$ pyroxsulam + one $\mathrm{HW}$ & $331.7^{\mathrm{bcd}}$ & $296.0^{\mathrm{c}-\mathrm{f}}$ & $50.77^{\mathrm{ef}}$ & $37.28^{\mathrm{de}}$ \\
\hline $\begin{array}{l}0.5 \mathrm{~kg} \mathrm{ha}^{-1} \text { clodinafop-propargyl } 6 \%+\text { fluroxypyr } \\
12 \%+\text { one HW }\end{array}$ & $284.7^{\text {fgh }}$ & $250.3^{\text {ghi }}$ & $42.11^{\mathrm{hi}}$ & $34.88^{\mathrm{gh}}$ \\
\hline $\begin{array}{l}0.75 \mathrm{~kg} \mathrm{ha}^{-1} \text { clodinafop-propargyl } 6 \%+\text { fluroxypyr } \\
12 \%+\text { one HW }\end{array}$ & $343.7^{\mathrm{bc}}$ & $301.3^{\text {cde }}$ & $51.83^{\mathrm{de}}$ & $38.31^{\mathrm{bcd}}$ \\
\hline $\begin{array}{l}1 \mathrm{~kg} \mathrm{ha}^{-1} \text { clodinafop-propargyl } 6 \%+\text { fluroxypyr } \\
12 \%+\text { one HW }\end{array}$ & $349.3^{\mathrm{b}}$ & $320.7^{\mathrm{bc}}$ & $57.90^{\mathrm{b}}$ & $39.40^{\mathrm{b}}$ \\
\hline $1 \mathrm{~kg} \mathrm{ha}^{-1} 2,4-\mathrm{D}$ amine salt & $248.7^{\mathrm{i}}$ & $222.0^{\mathrm{i}}$ & $36.33^{\mathrm{k}}$ & $33.14^{\mathrm{i}}$ \\
\hline $\begin{array}{l}0.75 \mathrm{~kg} \mathrm{ha}^{-1} \text { clodinafop-propargyl } 6 \%+\text { fluroxypyr } \\
12 \%\end{array}$ & $294.0^{\mathrm{efg}}$ & $267.0^{\mathrm{fgh}}$ & $44.27^{\mathrm{h}}$ & $35.75^{\mathrm{g}}$ \\
\hline $0.5 \mathrm{~kg} \mathrm{ha}^{-1}$ pyroxsulam & $304.7^{\mathrm{def}}$ & $269.7^{\mathrm{e}-\mathrm{h}}$ & $47.27^{\mathrm{g}}$ & $35.96^{\mathrm{fg}}$ \\
\hline Two HW 30 and 45 days after emergence & $358.0^{\mathrm{ab}}$ & $333.7^{\mathrm{b}}$ & $56.93^{b c}$ & $38.98^{\mathrm{bc}}$ \\
\hline Weed-free check & $386.3^{\mathrm{a}}$ & $367.3^{\mathrm{a}}$ & $61.40^{\mathrm{a}}$ & $41.92^{\mathrm{bc}}$ \\
\hline Weedy check (unweeded) & $172.7^{\mathrm{j}}$ & $149^{j}$ & $31.60^{\mathrm{i}}$ & $31.90^{j}$ \\
\hline LSD (5\%) & 31.89 & 31.97 & 2.99 & 1.15 \\
\hline $\mathrm{CV}(\%)$ & 6.30 & 6.98 & 3.80 & 1.88 \\
\hline
\end{tabular}

Means followed by the same letter are not significantly different at $5 \%$ level of significance. CV, coefficient of variation; LSD, least significant difference; HW, hand weeding.

than other treatments except weedy check. This lower quantity of tillers may probably be due to higher density of weeds causing unavailability of greater area, decreased nutrients, and moisture unavailability for the crop. The result is in keeping with the finding of Naveed et al. [33] who indicated that weeds are naturally robust competitor; they compete with crops for space, nutrient, moisture, light, and carbon dioxides and may lessen the yield components of the crop.

Influence of different weed management practices on productive tillers was extremely noteworthy. Similar to the number of total tillers, the highest number of productive tillers $\left(333.7 \mathrm{~m}^{-2}\right)$, next to weed-free check $\left(367.3 \mathrm{~m}^{-2}\right)$, was recorded from two hand weeding 30 and 45 days after crop emergence which is statistically at par with the use of pyroxsulam at the rate of $0.6 \mathrm{~kg} \mathrm{ha}^{-1}+$ one hand weeding and clodinafop-propargyl $6 \%+$ fluroxypyr $12 \%$ at $0.75 \mathrm{kgha}^{-1}+$ one hand weeding (Table 7). This higher number of productive tillers in two hand weeding 30 and 45 DAE over herbicide treatments and weedy check plots might be due to reducing soil compaction at earlier stage and creating good soil condition for better aeration resulting in 
more total and productive tillers' emergence. In addition to this, the higher tillers' number in hand weeding is due to early removal of weeds by hand which is the greatest operative way to prevent weeds that are resistant as well as tolerant to herbicides and therefore from becoming a serious problem as compared to herbicide control. The result was in accordance with the investigation of Ijaz et al. [34] who perceived that nutrient availability to the crop was due to better weed control which ultimately increased tillers that can bear spikes.

Grains spike ${ }^{-1}$ : perusal of the analysis of variance exhibited that the treatment difference with respect to grain number spike ${ }^{-1}$ was found to be pointedly dissimilar. From the experiment, it was obtained that higher grain number spike $^{-1}$ (57.9) with the application of clodinafop-propargyl $6 \%+$ fluroxypyr $12 \%$ at $1 \mathrm{~kg} \mathrm{ha}^{-1}+$ one hand weeding was statistically equal to two hand weeding 30 and 45 DAE, next to weed-free treatments which registered statistically the highest grains spike ${ }^{-1}$ (61.4). Significantly, this higher number of grains spike ${ }^{-1}$ may well be due to effective weed management methods that reduce weed density and dry matter with low weed infestation which resulted in lower weed competition for the same molecule of water and quantum of light and more absorption of ion of nutrients from soil due to less antagonism that helped the crop to gain more flowers resulting in higher number of grains in the absence of competition from weeds. The investigation was in agreement with the effort of Hassan et al. [35] who reported that the increase in grain number spike ${ }^{-1}$ may perhaps be recognized due to good weed control and obliteration of weed crop competition for the same ion of nutrients, molecule of water, and quantum of light as well as better use of available resources by the crop.

Minimum of grain number spike ${ }^{-1}$ (31.6) was obtained in unweeded plots followed by the application of 2,4-D amine salt at $1 \mathrm{kgha}^{-1}$ and 2,4-D amine salt at $0.5 \mathrm{~kg} \mathrm{ha}^{-1}+$ one hand weeding with 36.33 grains spike ${ }^{-1}$ and 38.7 grains spike ${ }^{-1}$, respectively. This might be due to that increasing density of weeds increases competition for available resources so that nutrient in the sink decreases resulting in abortion of flowers and finally to have minimum of grain number spike ${ }^{-1}$. The finding was in line with the effect of Zand et al. [36] who stated that grain number spike $^{-1}$ was considerably declined with the increase in weed severity and pointedly improved with the increasing duration of weed-free period.

Weight of thousand grains (g): the data concerning with 1000 -grain weight specified that there was substantial variance among different control treatments. 1000-grain weight under weed-free treatments was different from all other treatments that registered with the highest weight $(41.92 \mathrm{~g})$ (Table 7). Plants grown under weed-free condition were free from weed competition and exploited obtainable resources to their concentrated needs to gain higher seed weight. This higher 1000-grain weight under weed-free condition also might be due to no competition for nitrogen resulting in enough uptake during seed filling which plays an important role in maintaining green leaf area and thus assimilates supply to the growing seeds resulting in higher seed weight.
The outcome was in harmony with the result of Khalid et al. [37] who reported that the more and vigorous the leaves under weed free situations, the more assimilation has been stored in the grain to have grains weight.

Significantly heavier 1000-grain weight was recorded from the application of clodinafop-propargyl $6 \%+$ fluroxypyr $12 \%$ at $1 \mathrm{~kg} \mathrm{ha}^{-1}+$ one hand weeding, plots treated with two hand weeding 30 and $45 \mathrm{DAE}$, and the usage of pyroxsulam at $0.5 \mathrm{~kg} \mathrm{ha}^{-1}+$ one hand weeding with no statistical difference (Table 7). The superior 1000-grain weight with these integrated treatments was due to weeding at appropriate time by means of herbicide, and augmenting with hand weeding could provide encouraging location for the crop which provided ample opportunity for the crop to exploit available resources that leads to better grain filling, ultimately resulting in more 1000 -grain weight.

In contrast to this, lowest 1000 -grain weight $(31.9 \mathrm{~g})$ was obtained from unweeded plots followed by the expenditure of 2,4 D amine salt at $1 \mathrm{~kg} \mathrm{ha}^{-1}$ and 2,4 D amine salt at $0.5 \mathrm{~kg} \mathrm{ha}^{-1}+$ one hand weeding with no dissimilarity between these two treatments (Table 7). The lowest 1000-grain weight under weedy check is due to more weeds that cause much nutrient depletion from the soil and the more competition with crop plants for limitation of resources causes less mobility of nutrients to the crop plants resulting in lowered grain weight to be obtained.

Grain yield $\left(\mathrm{kg} \mathrm{ha}^{-1}\right)$ : statistical analysis of the variance exhibits that the mean wheat grain yield was suggestively inclined by different weed management treatments. Statistical analysis of the variance directed that the lay over wheat yield of $4,219.4 \mathrm{~kg} \mathrm{ha}^{-1}$ was recorded in weed-free check which was statistically different from the remaining treatments (Table 8 ). This significant increase in wheat grain yield under weed-free condition is plausible that crop plants are free from weed severity and thus used accessible resources to its supreme advantage to have a good stand that preferred intensification in yield attributes such as productive number of tillers, grains number spike ${ }^{-1}$, and 1000-grain weight resulting in increased wheat grain yield. The result was in accordance with the finding of $[29,38]$ which indicated that, from weed-free treatment, maximum grain yield of wheat was recorded.

Moreover, greater grain yield was obtained from the use of clodinafop-propargyl $6 \%$ + fluroxypyr $12 \%$ at $1.0 \mathrm{~kg} \mathrm{ha}^{-1}$ + one hand weeding, two hand weeding 30 and 45 DAE, pyroxsulam at $0.5 \mathrm{~kg} \mathrm{ha}^{-1}+$ one hand weeding, clodinafoppropargyl $6 \%+$ fluroxypyr $12 \%$ at $1 \mathrm{kgha}^{-1}+$ one hand weeding, and pyroxsulam at $0.6 \mathrm{~kg} \mathrm{ha}^{-1}+$ one hand weeding with $\quad 3635.6 \mathrm{~kg} \mathrm{ha}^{-1}, \quad 3547.1 \mathrm{~kg} \mathrm{ha}^{-1}, \quad 3494.5 \mathrm{~kg} \mathrm{ha}^{-1}$, $3443.5 \mathrm{~kg} \mathrm{ha}^{-1}$, and $3225.3 \mathrm{~kg} \mathrm{ha}^{-1}$, but no statistical variation was observed between them (Table 8). The inquiry of difference also indicated that superior wheat grain yield was obtained from herbicides if applied and supplemented with one hand weeding as compared to their sole application. The reason behind is the efficient management of weeds during initial time by herbicide application, and control of weeds later through hand weeding increases length of weed-free period to provide favorable location for the crop which eventually leads to better wheat grain yield. The current 
TABLE 8: Effect of weed control treatments on yield component and yield of wheat in 2020 main cropping season.

\begin{tabular}{|c|c|c|c|}
\hline Treatments & Grain yield $\left(\mathrm{kg} \mathrm{ha}^{-1}\right)$ & Biological yield $\left(\mathrm{kg} \mathrm{ha}^{-1}\right)$ & Harvest index (\%) \\
\hline $0.5 \mathrm{~kg} \mathrm{ha}^{-1} 2,4-\mathrm{D}$ amine salt + one $\mathrm{HW}$ & $2132.1^{\mathrm{fg}}$ & $6230.4^{\mathrm{ef}}$ & $34.11^{\text {hi }}$ \\
\hline $1 \mathrm{~kg} \mathrm{ha}^{-1} 2,4-\mathrm{D}$ amine salt + one HW & $2490.2^{\text {efg }}$ & $7274.1^{\text {de }}$ & $34.24^{\text {hi }}$ \\
\hline $1.5 \mathrm{~kg} \mathrm{ha}^{-1} 2,4-\mathrm{D}$ amine salt + one $\mathrm{HW}$ & $2929.0^{\text {cde }}$ & $7785.2^{\mathrm{cd}}$ & $37.56^{\text {def }}$ \\
\hline $0.4 \mathrm{~kg} \mathrm{ha}^{-1}$ pyroxsulam + one $\mathrm{HW}$ & $2725.4^{\text {de }}$ & $7539.0^{\mathrm{d}}$ & $36.10^{\mathrm{fg}}$ \\
\hline $0.5 \mathrm{~kg} \mathrm{ha}^{-1}$ pyroxsulam + one $\mathrm{HW}$ & $3494.5^{\mathrm{bc}}$ & $8867.4^{\mathrm{bc}}$ & $39.39^{\mathrm{bc}}$ \\
\hline $0.6 \mathrm{~kg} \mathrm{ha}^{-1}$ pyroxsulam + one HW & $3225.3^{\text {bcd }}$ & $8402.0^{\mathrm{bcd}}$ & $38.34^{\text {cde }}$ \\
\hline $0.5 \mathrm{~kg} \mathrm{ha}^{-1}$ clodinafop-propargyl $6 \%+$ fluroxypyr $12 \%+$ one $\mathrm{HW}$ & $2650.7^{\mathrm{ef}}$ & $7449.9^{\mathrm{d}}$ & $35.56^{\mathrm{gh}}$ \\
\hline $0.75 \mathrm{~kg} \mathrm{ha}^{-1}$ clodinafop-propargyl $6 \%+$ fluroxypyr $12 \%+$ one HW & $3443.5^{\mathrm{bc}}$ & $8859.7^{\mathrm{bc}}$ & $38.82^{\text {bcd }}$ \\
\hline $1 \mathrm{~kg} \mathrm{ha}^{-1}$ clodinafop-propargyl $6 \%+$ fluroxypyr $12 \%+$ one HW & $3635.6^{\mathrm{b}}$ & $9004.0^{\mathrm{b}}$ & $40.32^{\mathrm{ab}}$ \\
\hline $1 \mathrm{~kg} \mathrm{ha}^{-1} 2,4-\mathrm{D}$ amine salt & $2041.2^{\mathrm{g}}$ & $6051.7^{\mathrm{f}}$ & $33.68^{\mathrm{i}}$ \\
\hline $0.75 \mathrm{~kg} \mathrm{ha}^{-1}$ clodinafop-propargyl $6 \%+$ fluroxypyr $12 \%$ & $2822.0^{\text {de }}$ & $7641.6^{\mathrm{d}}$ & $36.86^{\mathrm{efg}}$ \\
\hline $0.5 \mathrm{~kg} \mathrm{ha}^{-1}$ pyroxsulam & $2828.3^{\text {de }}$ & $7612.5^{\mathrm{d}}$ & $37.13^{\text {efg }}$ \\
\hline Two HW 30 and 45 DAE & $3547.1^{\mathrm{b}}$ & $8885.4^{\text {bc }}$ & $39.89^{\mathrm{abc}}$ \\
\hline Weed-free check & $4252.8^{\mathrm{a}}$ & $10223.0^{\mathrm{a}}$ & $41.57^{\mathrm{a}}$ \\
\hline Weedy check (unweeded) & $1327.4^{\mathrm{h}}$ & $4524.8^{\mathrm{g}}$ & $29.23^{j}$ \\
\hline LSD $(5 \%)$ & 567.16 & 1217.5 & 1.68 \\
\hline CV (\%) & 11.69 & 9.38 & 2.73 \\
\hline
\end{tabular}

Same letter: means are not significantly different. CV, coefficient of variation; LSD, least significant difference; HW, hand weeding; DAE, days after crop emergence.

enquiry was in agreement with the study of Ansari et al. [39] who described that considerably advanced grain yield was acquired with amalgamation of manual and chemical weed control methods in wheat. In contrast to this, because of the maximum infestation of weeds, the lowest grain yield $\left(1,327.4 \mathrm{~kg} \mathrm{ha}^{-1}\right)$ was attained from weedy check. The reason is that the more the weeds, the more the nutrient depletion from the soil and the more their competition with crop plants that conspicuously concentrated the nutrient movement towards the grains which finally affected the grain development potential of the plant that resulted lower yield.

Aboveground dry biomass yield $\left(\mathrm{kg} \mathrm{Ha}^{-1}\right)$ : among weed management practices, statistically $(P<0.01)$ the highest aboveground dry biomass yield $\left(10,223 \mathrm{kgha}^{-1}\right)$ was recorded in weed-free treatment (Table 8). This highest aboveground dry biomass in weed-free treatment might be because crop plants utilized the resources efficiently that resulted in better vegetative growth of the plant, specially leaf for efficient photosynthesis for enhanced overall development of the crop plants. The result was in accordance with the finding of Ishaya et al. [40] who stated that the increased length of weed-free period decreases dry matter weight of weed.

Furthermore, ANOVA indicated that the greatest biological yield was attained with the use of herbicides accompanied with hand weeding than their sole application (Table 8). This is because weeding at appropriate time by herbicide and complementing with hand weeding could provide favorable environment for the crop providing a plenty chance to utilize available resources which ultimately leads to better biological yield. It is also plausible that good conquest of weed growth by hand weeding and chemical application leads to low competition by weeds for the same volume of space, quantum of light, and ion of nutrients by which the crop could utilize resources efficiently.

However, on the other hand, the lowest biological yield $\left(4,524.8 \mathrm{~kg} \mathrm{ha}^{-1}\right)$ was achieved from weed check plots associated to all other treatments. This lowest biological yield might be due to severe weed antagonism with the crop for growth and development factors, which might have constrained the improvement of the crop resulting in minimum dry matter accumulation in crop for lower yield. The finding was in agreement with the investigation of Pisal and Sagarka [25] who directed that considerably lowermost grain and straw yields were recorded in unweeded control in wheat.

Harvest index (\%): the uppermost harvest index (40.32\%), next to weed-free check $(41.57 \%)$, was recorded with the application of clodinafop-propargyl $6 \%+$ fluroxypyr $12 \%$ at $1.0 \mathrm{~kg} \mathrm{ha}^{-1}+$ one hand weeding followed by two hand weeding 30 and $45 \mathrm{DAE}$, but no substantial dissimilarity was detected between them (Table 8). The noteworthy growth in harvest index might be qualified to destruction of weed growth resulting in more accessibility of plant nutrients and space to wheat crop which favored utilization of photosynthetic assimilates for better wheat yield formation. This also may perhaps be due to that operational weed control could provide available nutrients for a proper growth of crop at flowering stage to increase the number of grain spike ${ }^{-1}$ and supply of more assimilates to the grain for more grain weight maintenance to have much yield, ultimately resulting in achieving higher possible harvest index. In the weedy check treatments, the mean minimum harvest index (29.23\%) that was significantly varied from all weed management practices was obtained. This lower harvest index may well be due to simple weed antagonism with the crop for available resources, which constrained the growth and development of the crop, leading to reduction in yield component and yield of the crop resulting in lowest harvest index in weedy check plots. In addition, soil moisture deficits due to weed competition persuades abortion of flowers and fruits, and the effect on yield may be more harmful than the consequence on biomass production. This current inquiry is in arrangement with the study of Raghavaiah and Zeki [28] who quantified 
TABLE 9: Effect of treatments on economic return in wheat in 2020 main cropping season.

\begin{tabular}{|c|c|c|c|c|c|}
\hline Treatments & $\begin{array}{l}\text { Total cost } \\
\left(\mathrm{ETB} \mathrm{ha}^{-1}\right)\end{array}$ & $\begin{array}{c}\text { Grain yield } \\
\left(\mathrm{kg} \mathrm{ha}^{-1}\right)\end{array}$ & $\begin{array}{l}\text { Adjusted yield } \\
\quad\left(\mathrm{kg} \mathrm{ha}^{-1}\right)\end{array}$ & $\begin{array}{l}\text { Gross benefit } \\
\left(\mathrm{ETB} \mathrm{ha}^{-1}\right)\end{array}$ & $\begin{array}{l}\text { Net benefit } \\
\left(\text { ETB ha }^{-1}\right)\end{array}$ \\
\hline $0.5 \mathrm{~kg} \mathrm{ha}^{-1} 2,4-\mathrm{D}$ amine salt + one HW & 4901.6 & 2132.1 & 1918.9 & 34156.2 & 29254.6 \\
\hline $1 \mathrm{~kg} \mathrm{ha}^{-1} 2,4-\mathrm{D}$ amine salt + one HW & 5472.1 & 2490.2 & 2241.2 & 39893.0 & 34420.9 \\
\hline $1.5 \mathrm{~kg} \mathrm{ha}^{-1} 2,4-\mathrm{D}$ amine salt + one HW & 6148.7 & 2929.0 & 2636.1 & 46922.5 & 40773.8 \\
\hline $\begin{array}{l}0.5 \mathrm{~kg} \mathrm{ha}^{-1} \text { clodinafop-propargyl } \\
6 \%+\text { fluroxypyr } 12 \%+\text { one HW }\end{array}$ & 5811.2 & 2725.4 & 2452.9 & 43660.9 & 37849.7 \\
\hline $\begin{array}{l}0.75 \mathrm{~kg} \mathrm{ha}^{-1} \text { clodinafop-propargyl } \\
6 \% \text { + fluroxypyr } 12 \%+\text { one HW }\end{array}$ & 6936.9 & 3494.5 & 3145.1 & 55982.0 & 49045.1 \\
\hline $\begin{array}{l}1 \mathrm{~kg} \mathrm{ha}^{-1} \text { clodinafop-propargyl } \\
6 \%+\text { fluroxypyr } 12 \%+\text { one } \mathrm{HW}\end{array}$ & 6698.1 & 3225.3 & 2902.8 & 51669.3 & 44971.2 \\
\hline $0.4 \mathrm{~kg} \mathrm{ha}^{-1}$ pyroxsulam + one $\mathrm{HW}$ & 5963.0 & 2650.7 & 2385.6 & 42464.2 & 36501.2 \\
\hline $0.5 \mathrm{~kg} \mathrm{ha}^{-1}$ pyroxsulam + one $\mathrm{HW}$ & 7124.8 & 3443.5 & 3099.2 & 55164.9 & 48040.1 \\
\hline $0.6 \mathrm{~kg} \mathrm{ha}^{-1}$ pyroxsulam + one $\mathrm{HW}$ & 7497.1 & 3635.6 & 3272.0 & 58242.3 & 50745.2 \\
\hline $1 \mathrm{~kg} \mathrm{ha}^{-1} 2,4-\mathrm{D}$ amine salt & 3042.2 & 2041.2 & 1837.1 & 32700.0 & 29657.8 \\
\hline $\begin{array}{l}0.75 \mathrm{~kg} \mathrm{ha}^{-1} \text { clodinafop-propargyl } \\
6 \% \text { + fluroxypyr } 12 \%\end{array}$ & 4213.1 & 2822.0 & 2539.8 & 45208.4 & 40995.3 \\
\hline $0.5 \mathrm{~kg} \mathrm{ha}^{-1}$ pyroxsulam & 4476.4 & 2828.3 & 2545.5 & 45309.4 & 40833.0 \\
\hline Two HW 30 and 45 days after emergence & 8260.9 & 3547.1 & 3192.4 & 56824.5 & 48563.6 \\
\hline Weed-free check & 19088.1 & 4252.8 & 3827.5 & 68129.9 & 49041.8 \\
\hline Weedy check (unweeded) & 1744.3 & 1327.4 & 1194.7 & 21264.9 & 19520.6 \\
\hline
\end{tabular}

Cost of pyroxsulam, $1200 \mathrm{ETB} / \mathrm{kg}$; cost of clodinafop-propargyl $6 \%$ + fluroxypyr 12\%, $460 \mathrm{ETB} / \mathrm{kg}$; for spraying, $160 \mathrm{ETB} / \mathrm{ha}$; cost of hand weeding for one time, 46 persons at ETB 40/person; cost of postharvest activities, $135 \mathrm{ETB} / 100 \mathrm{~kg}$; costs for packaging materials, packaging, and transportation, $11 \mathrm{ETB} / 100 \mathrm{~kg}$; sale price of wheat, $17.80 \mathrm{ETB} / \mathrm{kg}$. HW, hand weeding.

that the uppermost harvest index was recorded with the application of 2,4-D at $2.0 \mathrm{~kg} \mathrm{ha}^{-1}$ accompanied with hand weeding, while the lowermost harvest index was recorded from weedy check plots.

3.3. Partial Budget Analysis. The result of economic inquiry showed that the uppermost total variable cost $\left(8,260.9 \mathrm{ETB} \mathrm{ha}^{-1}\right)$ was recorded from two hand weeding 30 and 45 DAE next to weed-free check treatment which was registered with $19,088.1 \mathrm{ETB} \mathrm{ha}^{-1}$ (Table 9). On the other hand, highest net benefit $\left(50,745.2 \mathrm{ETB} \mathrm{ha}^{-1}\right)$ was obtained with the use of pyroxsulam at $0.6 \mathrm{~kg} \mathrm{ha}^{-1}+$ one hand weeding followed by the application of clodinafop-propargyl $6 \%+$ fluroxypyr $12 \%$ at $0.75 \mathrm{~kg} \mathrm{ha}^{-1}+$ one hand weeding and weed-free check plots of 49,045.1 $\mathrm{ETB} \mathrm{ha}^{-1}$ and 49041.8 $\mathrm{ETB} \mathrm{ha}^{-1}$, respectively. The maximum net benefit with the application of integrated weed management is because efficient management of weeds using chemical control with one hand weeding complemented provides upper grain yield and gross benefits with lower cost of construction, ultimately resulting in maximum net benefit. This analysis is in agreement with the study of Sureshkumar and Durairaj [41] who reported that chemical usage gives the most actual, economical, and practical method of weed control when supplemented with hand weeding.

\section{Conclusions}

The current research finding indicated that $93.3 \%$ highest weed control efficiency and $27.06 \%$ herbicide efficiency index were recorded with the application of clodinafoppropargyl $6 \%+$ fluroxypyr $12 \%$ at $1.0 \mathrm{~kg} \mathrm{ha}^{-1}$ supplemented with one hand weeding. Higher grain number spike ${ }^{-1}$ (57.9), 1000-grain weight (39.4 g), grain yield $\left(3,635.6 \mathrm{~kg} \mathrm{ha}^{-1}\right)$, aboveground biomass yield $\left(9,004 \mathrm{~kg} \mathrm{ha}^{-1}\right)$, and harvest index $(40.32 \%)$ were recorded from the application of clodinafop-propargyl $6 \%+$ fluroxypyr $12 \%$ at $1.0 \mathrm{~kg} \mathrm{ha}^{-1} \mathrm{ac}-$ companied with one hand weeding. Finally, the outcome of the study perceptibly specified that handling weeds with the usage of clodinafop-propargyl $6 \%+$ fluroxypyr $12 \%$ at $1.0 \mathrm{~kg} \mathrm{ha}^{-1}$ accompanied with one hand weeding is identified to be the most profitable practice in the study area.

\section{Data Availability}

The data used for analysis of the research results are available from the author upon request.

\section{Conflicts of Interest}

The author declares that there are no conflicts of interest.

\section{Acknowledgments}

I am grateful to the Lion International Trading Private Limited Company for their cooperation. My truthful gratitude is due to Webishet Alemu. This study was funded by the Lion International Trading Private Limited Company.

\section{References}

[1] Central Statistical Authority (Csa), The Federal Democratic Republic of Ethiopia, Central Statistical Agency Agricultural Sample Survey: Report on Area and Production of Major Crops (Private Peasant Holdings, Meher Season), Statistical Bulletin 580, Central Statistical Authority (Csa), Addis Ababa, Ethiopia, 2018/19. 
[2] B. Shiferaw, M. Kassie, M. Jaleta, and C. Yirga, “Adoption of improved wheat varieties and impacts on household food security in Ethiopia," Food Policy, vol. 44, pp. 272284, 2015.

[3] W. Assefa, N. Yemane, and H. Dawit, "Planting density and nitrogen and phosphorus fertilization effect on different bread wheat (Triticum aestivum L.) genotypes in Southern Tigray, Ethiopia," World Journal of Medical Science Research, vol. 3, no. 2, pp. 20-28, 2015.

[4] O. M. Nazarko, R. C. Van Acker, and M. H. Entz, "Strategies and tactics for herbicide use reduction in field crops in Canada: a review," Canadian Journal of Plant Science, vol. 85, no. 2, pp. 457-479, 2005.

[5] D. Delga, J. J. Sharma, and T. Tana, "Evaluation of herbicides and their combinations for weed management in Bread Wheat (Triticum aestivum L.) in Southern Ethiopia," International Journal of Novel Research in Life Sciences, vol. 1, no. 1, pp. 31-47, 2014.

[6] E. Bekele, F. Azerefegn, and T. Abate, Facilitating the Implementation and Adoption of Integrated Pest Management (IPM) in Ethiopia: Planning Workshop from October 13-15, 2003 at the Melkassa Agricultural Research Center, EARO, Addis Ababa, Ethiopia, 2006.

[7] M. Montazeri, "Weeds and control in wheat farms of Iran," Research and Education of Agriculture, vol. 85, 2005.

[8] O. A. C. Ologbon and S. A. Yusuf, "Economics of weed control practices on rice farms in Obafemi-owode area of Ogun state," Nigeria Journal of Agricultural and Biological Science, vol. 50, pp. 20-25, 2012.

[9] M. L. Kewat, "Improved weed management in Rabi crops," National Training on Advances in Weed Management, vol. 32, pp. 22-25, 2014.

[10] A. Malviya and B. Singh, "Weed dynamics, productivity and economics of maize as affected by integrated weed management under rainfed condition," Indian Journal of Agronomy, vol. 52, no. 4, pp. 321-324, 2007.

[11] Chena Woreda Finance and Economy Office (CWFEO), Statistical Abstract of the Chena Woreda, Chena Woreda Finance and Economy Office (CWFEO), Wacha, Ethiopia, 2019.

[12] MoA(Ministry of Agriculture), Animal and Plant Health Regulatory Directorate, Crop Variety Register, Issue No.12, MoA(Ministry of Agriculture), Addis Ababa, Ethiopia, 2009.

[13] B. Chandresekaran, K. . Annadurain, and E. Somasundaram, A Text Book of Agronomy: New Age International, P) limited publishers, New Delhi, India, 2010.

[14] International Maize and Wheat improvement Center (Cimmyt), From Agronomic Data to Farmer Recommendations: An Economics Training Manual, International Maize and Wheat improvement Center (Cimmyt), Mexico, USA, 1988.

[15] SAS Institute inc, SAS/STAT 9.22 User's Guide, SAS Institute Inc., Cary. NC.USA, 2009.

[16] K. T. Gomez and A. A. Gomez, Statistical Procedures for Agricultural Research, John Wily and Sons, New York, NY, USA, 2nd Ed. edition, 1984.

[17] N. S. Kumar, "Effect of plant density and weed management practices on production potential of groundnut (Arachis hypogaea L.)," Indian Journal of Agricultural Research, vol. 43, pp. 57-60, 2009.

[18] U. Wajeeh, N. Khalid, I. Shahid et al., "Effect of different weeding intervals and methods on the yield and yield components of maize (Zea maize L.)," Asian Research Publishing Network Journal of Agricultural and Biological Science, vol. 1, p. 3, 2016.
[19] P. Singh, V. Dhayani, P. Singh, A. Kumar, K. Singh, and T. Neeta, "Bioefficacy of pyroxsulam for weed control in wheat," Indian Journal of Weed Science, vol. 41, no. 3and 4, pp. 197-200, 2009.

[20] H. Sareta, W. Worku, and B. Begna, "Economics of herbicide weed management in wheat in Ethiopia," African Crop Science Journal, vol. 24, no. 1, pp. 109-116, 2016.

[21] M. Raize, MM. Azim, TZ. Mahmood, and M. Jamil, "Effect of various weed control methods on yield and yield components of wheat under different cropping patterns," International Journal of Agriculture and Biology, vol. 8, pp. 636-640, 2006.

[22] T. K. Das and N. T. Yaduraju, "Effect of weed competition on growth, nutrient uptake and yield of wheat as affected by irrigation and fertilizers," The Journal of Agricultural Science, vol. 133, no. 1, pp. 45-51, 1999.

[23] G. Mekonnen, J. Sharma, L. Negatu, and T. Tana, "Effect of integrated weed management practices on weeds infestation, yield components and yield of cowpea [vigna unguiculata (L.) walp.] in eastern wollo, northern Ethiopia," American Journal of Experimental Agriculture, vol. 7, no. 5, pp. 326-346, 2015.

[24] M. Iqbal, "Efficacy of herbicides and row spacing on weeds and yield and yield components of wheat," Sarhad Journal of Agriculture, vol. 1, pp. 23-41, 2003.

[25] R. R. Pisal and K. B. Sagarka, "Integrated weed management in wheat with new molecules," Indian Journal of Weed Science, vol. 45 , no. 1 , pp. 25-28, 2013.

[26] H. S. Mandal, H. M. Ali, R. M. Amin, M. S. Masum, and H. Mehraj, "Assessment of different weed control methods on growth and yield of wheat," International Journal of Applied Agricultural Research, vol. 5, no. 5, pp. 65-73, 2014.

[27] H. Patro and M. Ray, "Integration of chemical and cultural methods for weed management in wheat," Advance Research Journal of Crop Improvement, vol. 7, no. 2, pp. 207-210, 2016.

[28] V. Raghavaiah and T. Zeki, "Productivity, yield attributes and weed control in wheat (Triticum aestivum L.) as influenced by integrated weed management in central high lands of Ethiopia, east Africa," Advance of Crop Science Technology, vol. 4, p. 206, 2016.

[29] M. Kumar, A. Ghorai, S. Singh, B. Majumdar, D. Kundu, and B. Mahapatra, "Effect of stale seedbed and subsequent herbicides application on weeds and rhizospheric microorganism in Jute," in Proceeding of the 3rd International. Agron. Congress, pp. 304-305, New Delhi, India, June 2012.

[30] H. Mirza, I. Obaidul, and B. Shafiuddin, "Efficacy of different herbicides over manual weeding in controlling weeds in transplanted rice," Australian Journal of Crop Science, Southern Cross Journals, vol. 2, no. 1, pp. 18-24, 2013.

[31] O. Sunday and U. Ekea, "Evaluation of pre-emergence herbicides for weed control in cowpea (vigna unguiculata (L.) walp.) in a forest - savanna transition zone," American Journal of Experimental Agriculture, vol. 3, no. 4, pp. 767-779, 2013.

[32] A. S. Muhammad, A. N. Muhammad, M. N. Ghulam, and I. Furrkh, "Comparative efficacy of different post-emergence herbicides in wheat (Triticum aestivum L.)," Pakistan Journal of Agricultural Sciences, vol. 49, no. 1, pp. 27-34, 2012.

[33] M. Naveed, R. Ahmad, A. Nadeem, S. Nadeem, K. Shahzadand, and A. Anjum, "Effect of a new post emergence herbicide application in combination with urea on growth, yield and weeds control in maize (Zea mays L.)," Journal of Agricultural Research, vol. 46, no. 2, pp. 31-47, 2008.

[34] AK. Ijaz, G. Hassan, KB. Marwat, and I. Daur, "Efficacy of some pre and post emergence Herbicides on yield and yield components of canola," Pakistan Journal of Botany, vol. 40, pp. 1943-1947, 2008. 
[35] G. Hassan, B. Faiz, K. Marwat, and M. Khan, "Effects of planting method and tank mixed herbicides on controlling grassy and broadleaf weeds and their effect on wheat," Pakistan Journal of Weed Science Research, vol. 9, p. 111, 2003.

[36] E. Zand, MA. Baghestani, S. Soufizadeh, N. Bagherani, and R. Deihimfard, "Weed control and wheat (Triticum aestivum L.) yield under application of 2, 4-D plus carfentrazone-ethyl and florasulam plus flumetsulam: evaluation of the efficacy," Crop Protection, vol. 26, no. 12, p. 1759, 2007.

[37] Central Statistical Authority (CSA), 2016, The Federal Democratic Republic of Ethiopia, Central Statistical Agency Agricultural Sample Survey: Report on Area and Production of Major Crops (Private Peasant Holdings, Meher Season), Statistical Bulletin Central Statistical Authority (CSA), Addis Ababa, Ethiopia, 2009.

[38] R. Bharat, D. Kachroo, R. Sharma, and K. Sharma, "Effect of different herbicides on weed growth and yield performance of wheat (Triticum aestivum L.)," Indian Journal of Weed Science, vol. 44, no. 2, pp. 106-109, 2012.

[39] A. H. Ansari, A. D. Jarwar, H. I. Majeedona, T. M. Talpur, and L. S. Rajiput, "Study on integrated approach for weed management in wheat," Indus Journal of plant science, vol. 2, no. 4, pp. 340-344, 2003.

[40] D. B. Ishaya, P. Tunku, and N. C. Kuchinda, "Evaluation of some weed control treatments for long season weed control in maize (Zea mays L.) under zero and minimum tillage at Samaru, in Nigeria," Crop Protection, vol. 27, no. 7, pp. 1047-1051, 2008.

[41] R. Sureshkumar and Durairaj, "Weed characters and indices of transplanted rice as influenced by different weed management practices," International Journal of Agriculture Sciences, vol. 8, no. 51, pp. 2221-2223, 2016. 